\title{
Buli van? - Mitől lehet vonzó Budapest VII. kerülete a hazai fogyasztók számára?
}

\author{
Party time? - What makes Budapest District VII \\ attractive for domestic consumers?
}

\author{
Szerzők: Kiss Kornélia ${ }^{1}$ - Molnár-Csomós Ilona ${ }^{2}$ - Kincses Fanni ${ }^{3}$
}

A 2020 elején begyưrűzött Covid19-járvány előtt a túlturizmus jelenséggel érintett budapesti bulinegyed szinte egyik napról a másikra csendesedett el. Az újraindítás a "hogyan tovább"-ot illetően számos megválaszolásra váró kérdést vet fel. Jelen tanulmány kiindulási alapjául a túlturizmus és az élmény szolgál. Kutatási kérdésünk arra irányul, hogy mitől lehet vonzó Budapest VII. kerülete a szabadidôs fogyasztók és a belföldi turisták egyes, generációk mentén képzett szegmensei számára? Kérdésünk megválaszolásához a narratívaelemzést hívtuk segítségül, amelynek elvégzése a fogyasztók által emlékezetesnek ítélt élmény mélyebb szintű megértését és a kerület genius locijának azonosítását célozta. A narratívák alapján a VII. kerület olyan történelmi, kulturális, művészeti és társadalmi értékekkel rendelkezik, amelyeken keresztül azonositható a fogyasztók minden generációja számára vonzó genius loci.

The party tourism and overtourism phenomena characteristic of Budapest, District VII, prior to the Covid19 pandemic, in early 2020, fell silent almost overnight. The relaunch raises a number of questions regarding "how to continue". The starting-point of the present study is the theoretical overview of overtourism and the experience, as well as the genius loci that can be interpreted as a possible factor of the latter. Our research question focuses on what makes Budapest District VII for leisure consumers and for domestic travelers, segmented by generations, attractive? To answer our question, we used narrative analysis to help us gain a deeper understanding of the experience that consumers find memorable and identify the genius loci of the district. Based on the narratives, District VII has historical, cultural, artistic and social values that make it possible to identify a genius loci that is specifically linked to the area and makes it unique to all generations of consumers.

Kulcsszavak: túlturizmus, élmény, genius loci, bulinegyed, újrapozícionálás.

Keywords: overtourism, experience, genius loci, party district, repositioning.

\section{Bevezetés}

A túlturizmus (overtourism) jelenség által érintett budapesti romkocsmák elmúlt évekbeli, korábban soha nem látott ütemú növekvó népszerúségének (SMITH et al. 2019) megálljt parancsolt az Európába 2020 elején begyúrúzött Covid19járvány és az annak kezelésére hozott intézkedések, ami a "hogyan tovább"-ot illetóen számos megválaszolásra váró kérdést vet fel. A mérleg egyik serpenyőjében a bizonytalanság van, ami a kialakult helyzet normalizálódásának lehetséges idôpontja tekintetében a legjelentősebb (PINKESZIVA 2021), a másik serpenyójében azonban azok a lehetséges szcenáriók, amelyek a járvány kitörése előtti helyzethez viszonyítva, kisebb-nagyobb elmozdulás mentén értelmezhetôk.

A járvány megfékezésére bevezetett korlátozások idôszaka jó lehetóséget biztosít annak vizsgálatára, hogy kiket megszólítva és mire alapozva lehetséges a jelenleg sokszor bulinegyedként hivatkozott, Budapest VII. kerületében található turisztikai és vendéglátóipari vállalkozások újraindítása. Vélelmezhető, hogy a külföldről érkezők számának legalább idóleges csökkenése a belföldi

\footnotetext{
egyetemi docens, Budapesti Corvinus Egyetem, kornelia.kiss@uni-corvinus.hu

2 PhD-hallgató, Budapesti Corvinus Egyetem, ilona.csomos@uni-corvinus.hu

3 egyetemi hallgató, Budapesti Corvinus Egyetem, fanni.kincses@stud.uni-corvinus.hu
} 
turizmus, illetve a budapestiek szabadidős keresletének nagyarányú térnyerésével párosul. Az ebből fakadó célcsoportváltás tudatos menedzsmentje segítséget nyújthat a tömeg- és a túlturizmus féken tartásában, illetve ezzel párhuzamosan a turisták viselkedésével, a nagy zajjal, a megromlott közbiztonsággal, valamint a köztisztasággal kapcsolatos lakossági panaszok (PINKE-SZIVA et al. 2019) mérséklésében.

Jelen tanulmány kiindulási alapjául a túlturizmus és az élmény, illetve az annak egy lehetséges tényezőjeként értelmezhető genius loci (hely szelleme) elméleti áttekintése szolgál. Kutatási kérdésünk arra irányul, hogy mitől lehet vonzó Budapest VII. kerülete a budapesti szabadidős szolgáltatásokat igénybe vevôk és a belföldi turisták különbözô generációinak (Z, Y, X és Baby Boomer generációk) szegmensei számára? Ennek megválaszolásához a narratívaelemzést hívtuk segítségül, melynek elvégzése a fogyasztók által emlékezetesnek ítélt élmény mélyebb szintú megértését és a kerület genius locijának azonosítását célozta.

\section{Szakirodalmi áttekintés}

Az UNWTO (2018) definíciója alapján a túlturizmus egyenértékú a turizmusnak adott desztinációra vagy annak egy részére gyakorolt azon hatásával, amely a helyi lakosok életminőségének és jóllétének csökkenésében mutatkozik meg, mindamellett, hogy a turizmusban fogyasztóként résztvevők által megélt élmények minőségére is negatívan hat. Általánosságban véve a túlturizmus kifejezést a turizmus adott desztinációra gyakorolt negatív hatásaival hozzák összefüggésbe.

A jelenséggel foglalkozó írások megléte az 1960-as évekig vezethető vissza (KOENS et al. 2018). Az 1970-es években kezdtek el foglalkozni azon elméletek és indikátorok - a három alapvetó indikátor a felvevőképesség, a kapacitás és a flow (KRUCZEK 2019) - kidolgozásával, amelyek segítségével megállapíthatóvá vált az adott desztinációba érkező turisták optimális száma. DOXEY (1975) a helyi lakosság magatartásának a turizmus fejlódésével párhuzamos változását vizsgáló Irridexmodellt ugyancsak ekkortájt alkotta meg. Ezt követően BUTLER (1980) létrehozta a turisztikai desztinációk életciklus modelljét, ami a marketing egyik alapvető koncepciójára - a termékek piaci jelenlétének és élettartamának kapcsolatából felírható, szakaszokra bontható életciklus - épült. Az 1980-as évek közepén PIZAM és MILMAN (1986) megkísérelte a társadalmi hatások kategóriákba sorolását, melyek segítségével számszerúsíthetô az adott helyszín turistabefogadó képességének negatív következményekkel még nem járó felső li- mitje. Egy a későbbiekben kialakított alternatív elmélet, ami az elfogadható szintú változás modellje (Levels of Acceptable Change - LAC model) nevet viseli, azon a feltevésen alapul, miszerint a helyi lakosok és vállalkozók tolerancia szintje eltolódik abban az esetben, ha gazdasági érdek fúződik a fejlesztésekhez és a múködtetéshez, melynek okán hajlamosabbá válnak a turizmus okozta negatív hatásokkal szembeni nagyobb mértékú toleranciára (KRUCZEK 2019).

A túlturizmus okozta negatív hatások eredete és köre szerteágazó, emellett maga a jelenség is számos területtel áll lényegi összefüggésben. Napjainkban (a világjárvány előtti nagyjából egy évtizedben) a turizmus, így a túlturizmus negatív hatásai közül is kiemelt jelentőséggel bír a helyi lakosság esetében megtapasztalható életminőségromlás és jóllétcsökkenés, amely kapcsán KOENS és szerzőtársai (2018) öt, eltérő hatáskörrel és megjelenési formával rendelkezó problémakört különítenek el. Lévén, hogy a hatások leginkább a társadalmi, gazdasági és fizikai környezethez köthetők, a túlturizmus által okozott problematikus helyzet feloldásához a turisztikai fejlesztések városfejlesztési szempontok mentén történő újragondolása szükséges.

A túlturizmus fentiekben részletezett multidimenzionális jellegéból és az érintettek (turisták, szabadidős fogyasztók, helyi lakosság, turizmusban érintett és nem érintett vállalkozások, önkormányzat, stb.) széles köréból adódik a hatások ellensúlyozásának kihívásokkal teli mivolta. A problémák orvoslására megoldást jelenthet bizonyos tevékenységek betiltása, az AirBnB szállások ellenőrzése, korábbi zárási idő bevezetése, az erősebb rendőri jelenlét, a polgárôrség megszervezése, a jobb közvilágítás, a zajszigetelés, a közterületek gyakoribb takarítása, a közhasználatú mosdók számának növelése, a turisták magatartásának szabályozása vagy a tömeg menedzselését támogató, okostechnológiai-megoldások bevezetése (KOENS et al. 2018, PINKE-SZIVA et al. 2019). A túlturizmus kezelését szolgáló menedzsment módszerek egyike az az egyre gyakrabban alkalmazott eljárás, mely az érintett desztináció látogathatóságának limitálását célzó szabályozások és korlátozások bevezetésén alapul (KRUCZEK 2019). Lévén, hogy a túlturizmus jelenléte az éjszakai gazdaságban jellemzô, jó megoldásnak bizonyulhat az éjszakai polgármesteri tisztség bevezetése (PINKE-SZIVA et al. 2020). További, a gyakorlatban is alkalmazható megoldás a hosszútávon is vonzó, minden érintett számára elfogadható és hiteles imázs kialakítása (PINKE-SZIVA et al. 2020). Ezzel növelni lehet a desztinációban töltött éjszakák számát, a bevételeket, és olyan utazói csoportokat lehet megszólítani, 
akik magasabb költéssel jellemezhetőek és más - a helyiek életvitelével jobban összeegyeztethető, őket mindennapi tevékenységeikben kevésbé zavaró programok iránt is érdeklődnek.

A fogyasztói élmény az 1980-as években (ZÁTORI 2014) került a kutatók érdeklődésének középpontjába. PINE és GILMORE (1998) az aktív és passzív fogyasztói részvétel, valamint a fogyasztó és a tevékenység közti kapcsolat - úgymint belemerülés és figyelemlekötés - mértéke alapján az élmény négy dimenzióját határozta meg. PINE és szerzőtársa továbbá azt is megállapították, hogy az élményeket minden egyes személy máshogyan éli meg, illetve, hogy az élmény abban az esetben jön létre, ha a fogyasztó részérôl a tudás szintjén, valamint spirituális, érzelmi és fizikai szinteken is megtörténik az élményben való részvétel, az elmélyülés. LENGYEL (2019) az élménnyel kapcsolatos átélés mélységének fontosságát is hangsúlyozza, amelyre befolyással van az adott élmény átélésében érintett személy nyitottsága. A tényleges élmény megvalósulásának feltétele a gazdag összetétel, valamint a tényezők közti összhang megléte, kulcsfontosságú szerepet játszik benne továbbá a design, a kreativitás és az innováció. CARU és COVA (2007) élmény definíciója szerint a szolgáltató csak a kontextust teremti meg, azt a környezetet, melyben az élmény létrejön, míg magát az élményt a szolgáltató és a fogyasztó - a fogyasztói részvétel által - közösen hozzák létre.

$\mathrm{Az}$ élmények keresésére nagy hatással van a fogyasztói magatartás változása. SZABÓ és HÁMORI (2006) szerint ehhez a váltáshoz hozzátartozik az is, hogy - a választási lehetôségek bővülése mellett - a döntéshozatal felgyorsul, és a fogyasztói preferenciák egyre összetettebbé válnak, amelynek következtében a fogyasztói döntések kimenetele egyre nehezebben predesztinálható. APOLLO és RETTINGER (2019) mindamellett, hogy a fentieket megerôsíti, azt is hangsúlyozza, hogy a fogyasztói preferenciarendszeren belül a szórakozás, a tanulás, az izgalom, az élmény és az érzelmek egyre inkább előtérbe kerülnek. ZEMLA (2020) tanulmánya ugyancsak ezt a vált(oz)ást erősíti meg.

PINE és GILMORE (1998) szerint a személyes vonatkozás mellett az emlékezetesség az élmény legfontosabb tényezóje. Az élménygazdaságokban a kínálati oldalon álló szolgáltatók a fogyasztói élmény növelése érdekében az alapszolgáltatás folyamatos fejlesztése és tökéletesítése mellett igyekeznek többletszolgáltatást nyújtani. Ezen vállalkozások célja, hogy a fogyasztók figyelmét kiemelkedő élményt nyújtva nyerjék el, hisz az élmények a versenytársaktól való megkülönböztetésben is szerepet játszanak (BINKHORST-DEKKER
2009). MICHALKÓ és IRIMIÁS (2011) kiemeli az elvárásoknak való megfelelés jelentőségét, mivel csalódottsághoz vezet, ha az élmény ezzel nem találkozik.

Az élmény a turisztikai iparág egyik központi és meghatározó fogalma. BINKHORST és DEKKER (2009) szerint az élmények egyik legfontosabb generátorának a turizmus tekinthető. A turisztikai élmény által képessé válhatunk adott tevékenység vagy esemény értelmének megfogalmazására (KULCSÁR 2015). AHO (2001) a turisztikai élmény négy típusát különíti el: az emocionális élményt, a gyakorlati élményt, az informatív élményt és a transzformációs élményt. MICHALKÓ és RÁTZ (2005) az élmény legfontosabb tényezőit a valós vagy valósnak vélt veszélyben, az esztétikumban, az újdonságban, a kalandban, az izgalomban, az egzotikumban, az új tudás és készség megszerzésében, a társaságban, valamint az együtt töltött időben nevesíti. A turizmusban elmozdulás érzékelhető az olyan élmények irányába, amelyek autentikusak és képesek tudás átadására (GARCIA 2018). ZÁTORI (2014) kiemeli, hogy az utazások során az élmények megosztásának lényeges dimenzióját jelentik az olyan társadalmi interakciók, mint az új kapcsolódások kialakítása és a régi ismeretségek ápolása a közösen eltöltött idôn keresztül.

GARCIA (2018) úgy véli, hogy az emlékezetes turisztikai élmény (Memorable Tourism Experience - MTE), ami mindenki számára elérhető, szuperior élménynek is nevezhetô. KIM és szerzőtársai (2012) az emlékezetes turisztikai élmény hét lehetséges tényezójét nevesítik. Ezek a hedonizmus, az újdonság, a helyi kultúra, a feltöltődés, az értelem, a tudás és a bevonódás. GARCIA (2018) az MTEfaktorok mellett olyan további jelentős tényezóket azonosít, amelyek segítik egy élmény emlékezetessé válását. ZÁTORI és szerzótársai (2018) pedig olyan tényezőket helyeznek vizsgálódásuk középpontjába, amelyek az élmények emlékezetességét és autentikusságát növelik.

Az élmény fogalmával szoros összefüggésben álló genius loci, avagy a hely szelleme, egy helyszín megfoghatatlan karakterisztikáját jelenti, amihez szorosan kötődik a fizikai környezet, emiatt fizikai és spirituális módon együttesen tapasztalható meg. CHRISTOU és szerzótársai (2019) a turizmusfejlesztés és a genius loci kapcsolatát vizsgáló tanulmányukban úgy találták, hogy a kutatások sok esetben annak ellenére sem foglalkoznak magával a hely szellemével, hogy a fogyasztók ahhoz tudnak igazán kapcsolódni. Mindezek fényében láthatóvá válik az élmény és a genius loci között húzódó párhuzam, lévén, hogy mind a tényezôk, mind a dimenziók tekintetében átfedés figyelhető 
meg. Ahogy az az 1. ábrán látható, a genius loci tényezői három fő csoportba sorolhatók. Az élmény kérdéskörével kapcsolatos modellekben és kutatásokban a fizikai, a társadalmi és a spirituális tényezők mindegyike meghatározó szerephez jut.

\section{A genius loci tényezôinek csoportosítása}

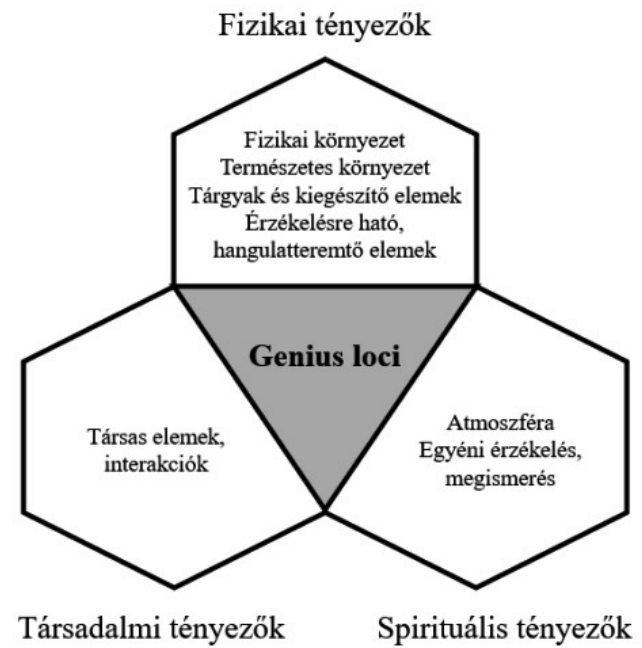

Forrás: saját szerkesztés CHRISTOU et al. (2019) alapján

A fizikai tényezôk szerepe kiemelten fontos az esztétikai élmény és a helyi kultúra vonatkozásában mindamellett, hogy megalapozza az adott helyszín egyediségét is. Az élménnyel foglalkozó szakirodalomban az érzékelésre gyakorolt hatás fontosságán túl - amelynek a mélyebb és emlékezetesebb élmény elérésében van kulcsszerepe - számos helyen megjelennek a társadalmi tényezók is. A tényezók harmadik csoportját alkotó spirituális tényezők élménnyel kapcsolatos előfordulása szintén számottevő. Az atmoszféra és az egyediség révén a spirituális tényezók szerepet játszanak az élményben való elmélyülésben, az élmény maradandóságában, valamint annak erősítésében, hogy a fogyasztó egyedi érzékelése és gondolatvilága is befolyással bír az élményre.

Ahogy azt a korábbiakban láthattuk, a túlturizmusban érintett desztinációkban a helyi lakosok életminőségének megóvása és javítása érdekében az érintettek végsố céljaként olyan imázs, márka és élményígéretek meghatározása kívánatos, amelyeknek a fenntartható módon történő biztosítása magas fogyasztói elégedettségi szint elérése mel- lett valósítható meg. Hazai viszonylatban a túlturizmus hatásai kiváltképp a Budapest VII. kerületi Belső-Erzsébetvárosban váltak érzékelhetővé. Az itt elhelyezkedő art- és romkocsmák a fôváros turisztikai palettájának különleges és egyedi részét képezik (KELEMEN-ERDŐS-MITEV 2020), aminek köszönhetôen - a világjárvány előtti idôkben - Belső-Erzsébetváros nemzetközi hatókörú desztinációvá vált. A VII. kerület azonban nemcsak turisztikai célterület, hanem több tízezer ember lakóhelye is, egy hétköznapiságában is megtapasztalt, autentikus miliôvel átitatott élettér. Tanulmányunk primer kutatási részében a kerület lehetséges márkájának és élményígéreteinek alapjául szolgáló genius locit vizsgáljuk, a kerület nyújtotta szolgáltatások lehetséges célcsoportjait képező szegmensek közül a nem a kerületben élő budapestiek és a belföldi turisták körében.

\section{A kutatás módszere}

Kutatási kérdésünk megválaszolásához a narratívaelemzést hívtuk segítségül a kvalitatív kutatási módszerek eszköztárából. A narratívaelemzés során a fogyasztók által megírt és elmesélt történetek elemzésével kapunk válaszokat a korábban feltett kérdésekre (HORVÁTH-MITEV 2015). A módszer alkalmazásához először a kutatás célját határoztuk meg, és hogy kik legyenek a résztvevők, majd kiválasztottuk, hogy milyen típusú történetet - személyes történet formájában készített beszámoló egy elképzelt emlékezetes élményrôl - készítsenek a résztvevők. A kutatás a történetek begyújtésével, elemzésével és értelmezésével folytatódott. Az elbeszélés szabadságának növelése érdekében az alaptéma megadása mellett csak a terjedelmi korlátok szabtak határt az élménybeszámolóknak. Ily módon vált biztosíthatóvá, hogy az elképzelt élmények leírása kellő részletességgel történjen. Az elbeszélés szabadságát támogatta az a kutatói kérés is, hogy a gondolatok megfogalmazása a megkérdezettek saját szavaival történjen, úgy, mintha a válaszadó egy barátnak vagy családtagnak mesélne. A narratívafeladat ${ }^{4}$ alanyokhoz történó eljuttatása 2021 márciusában online eszközök segítségével valósult meg, az elkészült narratívák szintén online felületen érkeztek vissza. Jelen tanulmányban húsz narratíva elemzésére kerül sor.

A mintavétel során a nem véletlen módszerek közül az önkényes és a hólabda technikák alkalmazására esett a választás. Mintánkban a női vá-

\footnotetext{
${ }^{4}$ A megkérdezettek az alábbi feladatot kapták: „Kérem képzelje el a következő helyzetet! Néhány év múlva, amikor a koronavírus-járvány elmúltával visszarendeződik az élet, úgy dönt, hogy ellátogat a VII. kerületbe (másnevén a bulinegyed, Zsidónegyed, Erzsébetváros). Írjon erről az alkalomról egy történetet, beszámolót úgy, mintha egy barátiának vagy családtagjának mesélne az ott szerzett élményeiről. Mitől érezte jól magát ezen a napon, milyen élményekkel gazdagodott? A történet terjedelme legalább egy oldal (kb. 3000 karakter) legyen. Annak, hogy pontosan miről ír, csak az Ön képzelete szab határt!"
} 
laszadók felülreprezentáltak, mivel a húsz válaszadó közül csak minden ötödik válaszadó volt férfi (1. táblázat).

A válaszadók életkori összetétele széles spektrumot ölelt fel. A válaszadók életkori öszszetételén túl a narratívaelemzés, a demográfiai tényező́k feltárására hivatott rész segítségével, a lakhely kérdéskörére is kitér. A megkérdezettek legnagyobb arányban Budapesten (8 fô), valamint

\subsection{FIZIKAI TÉNYEZÖK}

A három fó tényezô közül elóször a fizikai tényezők - úgymint fizikai, statikus környezet, valamint az építészettel kapcsolatos strukturális elemek kerülnek górcső alá, amelyek esetében a generációs különbség csekély mértékben van jelen. Eltérés abban mutatkozik, hogy milyen részletességgel írnak minderról.

A narratívák készítôinek lakhely, generáció és nem szerinti megoszlása

\begin{tabular}{|c|c|c|c|c|c|c|c|c|c|c|c|c|c|}
\hline LAKHELY & & \multicolumn{4}{|c|}{ Budapest } & \multicolumn{4}{|c|}{ Agglomeráció } & \multicolumn{4}{|c|}{ Vidék } \\
\hline GENERÁCIÓ & & $\begin{array}{c}\text { Baby } \\
\text { Boomer }\end{array}$ & $X$ & $Y$ & Z & $\begin{array}{c}\text { Baby } \\
\text { Boomer }\end{array}$ & $X$ & $Y$ & Z & $\begin{array}{c}\text { Baby } \\
\text { Boomer }\end{array}$ & $X$ & $Y$ & Z \\
\hline \multirow{2}{*}{ NEM } & Nô (16 fó) & & 2 & 3 & 2 & 1 & 1 & & 2 & 1 & 1 & & 3 \\
\hline & Férfi (4 fö) & 1 & & & & 1 & 1 & 1 & & & & & \\
\hline
\end{tabular}

Forrás: saját szerkesztés

a főváros vonzáskörzetében (7 fó) élnek, míg a megkérdezettek egy negyedének lakhelyéül falu, község vagy megyeszékhely szolgál.

\section{Eredmények}

A narratívák alapján két olyan tábor képe körvonalazódik, melyek véleménye jelentős mértékben eltér. A véleményalkotók első csoportjának kinyilatkoztatásai arra utalnak, hogy a pandémiát követóen nem sok minden változik majd, és a járványhelyzet kialakulását megelőző állapotok térnek vissza. A második csoport véleményeiben azonban a bíztató jövókép jelei látszódnak, amelyek a fejlódésben és a túlturizmus jelenségének hatékonyabb kezelésében öltenek testet.

A narratívák alapján a hedonizmus, az újdonság és a feltöltódés minden korosztály számára vonzó élménytényezóként jelenik meg. A helyi kultúra és a tudás iránti érdeklódést inkább az X és a Baby Boomer generációkba tartozó válaszadók említik. Szintén az idősebbeknél gyakori a nosztalgia érzésének megjelenése. Az eszképizmus - köszönhetóen a pandémia következtében kialakult bezártságnak is - a narratívákban ugyancsak sokszor fordul elô. A válaszok alapján elmondható, hogy a kerületben eltöltött idő aktív személyes jelenlét formájában valósul meg, és csak bizonyos kulturális programok esetében jellemzô a passzív fogyasztói szerepvállalás.

Ahhoz, hogy az élményígéretek alapjául szolgáló genius loci a narratívák elemzésével testet ölthessen, a CHRISTOU és szerzőtársai (2019) által létrehozott genius loci metakoncepció adta a kiindulási alapot (1. ábra).
A véleményekre ható legnagyobb mértékú befolyásoló tényező az, hogy a válaszadó milyennek képzeli el a kerület jövőjét. Szembetúnő, hogy minden generációból van olyan, aki hangot ad az építészeti értékeknek, az épületeknek és a szúk utcáknak, kiemelve azt is, hogy a 19. századot idézó bérházak, az ódon, történelmet sugárzó épületek nyújtotta hangulat nagy jelentôséggel bír. Az ilyesfajta hozzáadott értékre negatívumként tekint a válaszadók azon köre, akik az állapotok változatlanságát vizionálja. Azok ugyanakkor, akiknek a szeme előtt biztató jövôkép lebeg, felújított épületekről és terekről, valamint rendezett utcaképről írnak.

Többen megemlítik a kerület sokszínúségét, valamint azt, hogy itt szinte minden megtalálható. $\mathrm{Az} X$ generációs válaszadók közül hárman is pozitívumként könyvelik el a kerékpárutak bővítését, míg a fiatalabb generációk tagjai kitérnek annak fontosságára, hogy sétával szinte minden könnyen megközelíthető. Az optimizmus és a pesszimizmus egyidejû́ jelenlétét a soron következó idézetek is kiválóan példázzák:

„Budapest egy gyönyörú város. Akármerre néz az ember, magát a történelmet látja, az ódon épületeket, (...). Mind hazaiként, mind a külföldiek szemével vizsgálva egy kincsesdoboz."

$$
\text { \#nôZZgen_vidéki }
$$

„A területen utcáról utcára cikázva, már inkább leromlott állapotú, málladozó vakolatú épületekkel találkozhatunk, melyek már régóta várják, hogy régi pompájukban pompázhassanak." \#férfiBabyBoomer_vidéki 
A fizikai tényezők közé tartozik továbbá a természetes környezet, a tárgyak és a kiegészítő statikus elemek, úgymint a berendezések és az érzékelésre ható hangulatteremtő elemek. A természetes környezet fontossága leginkább az X és a Baby Boomer generációkba tartozó válaszadók esetében figyelhetô meg, közülük, többen is írnak a parkosításról, a növekvő zöld területekrôl és a növényekrôl, amivel egy élhetőbb és sétára invitáló környezet kialakításának a szükségességét közvetítik. Ehhez a vágyott környezethez tartozik a zaj, a szagok és a hulladék mennyiségének csökkentése, a tisztán tartott utcák és a közbiztonság növelése. Mindezt a válaszadók egyértelmúen párhuzamba állítják a buliturizmus és a külföldi turisták jelenlétével, helyesebben annak hiányával. A Z és az Y generációba tartozó megkérdezettek a hangulatot emelő zene mellett a design fontosságát hangsúlyozzák, amire a túzfalakon megjelenó street art alkotásoknak, a romkocsmák, az éttermek és a kávézók stílusának, kialakításának és berendezésének a dicséretével vagy egy romos fal előtt való fotózkodás lehetôségével utalnak.

\subsection{TÁRSADALMI TÉNYEZŐK}

A genius loci modell következô eleme az adott desztinációban tartózkodók között létrejövő interakciókkal kapcsolatos társadalmi tényezők köre.

A kedvesség és a vendégszeretet kettősének megléte a fogyasztók részéről olyan alapvetó elvárás, ami könnyedén válik az utólagos fogyasztói értékelések kritikus pontjává. Fontos terület továbbá a kerületben tapasztalható zsúfoltság és tömeg kérdése, ami folyamatosan megoldandó feladatokat generál. A narratívák alapján minden generáció számol azzal, hogy a kerület újranyitása után visszatér a tömeg, azonban ennek módja és megítélése változó. Az X és a Baby Boomer generációk képviselőinél egyértelmúen negatív színezetben kerül szóba a tömegek újbóli megjelenésével összefüggó okfejtés. Ezzel szemben a Z és az Y generációs válaszadóknál előfordul olyan, aki már „megszokta” a tömeget, sőt ismerkedési lehetôségként tekint rá.

"Itt mindig hatalmas a tömeg, amit annyira nem kedvelek, de ez egy velejárója az ilyesmi programoknak, ráadásul jól elszórakozunk a bejutáshoz való sorban állas közben is."

$$
\text { \#nôYgen_budapesti }
$$

„Ebéd és kávézgatás közben figyeltem az arra sétáló embereket, és rájöttem, hogy nagyon zsúfolt ez a környék. Nem tudnám elképzelni, hogy hosszabb idôt itt eltöltsek egy napnál."

$$
\text { \#nôXgen_budapesti }
$$

Többen azonban a változások elkerülhetetlen szükségessége mellett voksolnak, melynek vélhető következményeként a belföldi fogyasztók magasabb arányú jelenléte lesz megfigyelhetô.

\subsection{SPIRITUÁLIS TÉNYEZÖK}

A genius loci modell harmadik fő tényezője a spirituális tényezők csoportja. Ide tartozik az adott hely atmoszférájának milyensége, valamint az egyéni érzékeléssel és megismeréssel összefüggó tapasztalások.

A kerület atmoszférájának vizsgálat alá vonásához a fizikai és a társadalmi elemek jelentôs mértékben járulnak hozzá, és meg is alapozzák azt. Egy helyszínnek az épületek, az építészet, valamint a belsó design adja meg a karakterét, ami azt történelemmel, történetekkel tölti fel, melyeket érezni lehet, és ezáltal a helyre jellemzó különleges hangulatot áraszt a látogatók felé. A nosztalgia érzését elő tudja hozni egy tárgy vagy akár egy stílus, de a narratívák alapján a vidéki élet hangulata is megidézhetôvé válik, akár még a belváros kellős közepén is.

A hazai fogyasztók a szabad térhez és a teraszokhoz egy sajátos érzést társítanak. Egy olyan kellemes és pihentetô hellyel azonosítják, ahol akár órákat is el lehet tölteni. Ezért óriási jelentősége van annak, hogy kik és mekkora létszámban töltik meg az adott területet. A válaszadók általánosságban írnak arról, hogy a járványhelyzet javulását követôen mennyire mozgalmas, élettel teli és felpezsdült hangulat lett úrrá ismét a kerület utcáin. Az idősebbek esetében elmondható, hogy ők inkább a nyugalmat preferálják. A nyüzsgés állandósulása kapcsán többen is említik, hogy nem szívesen élnének a kerületben, sokkal inkább csak rövid látogatások idejére tartózkodnának itt.

„Az itt fellelhetô házak mind, egytôl egyig régies, különleges hangulatot árasztanak magukból, ezenkívül pedig elmondható, hogy a szúk utcákon sétálva éreztem, szinte átéltem a hely különleges atmoszféráját."

$$
\text { \#nőZgen_vidéki }
$$

"Régen szerettem, hogy nyüzsgés volt, de nyugdijasként már a nyugalom fontosabb. Most már inkább a fiataloknak való hely, ahogy a séta közben láttam, sok szórakozóhely van a környéken. Engem biztosan zavarna esténként a hangoskodás."

$$
\text { \#férfiBabyBoomer_budapesti }
$$

A VII. kerülethez kötődő élményekkel kapcsolatos válaszok arról tanúskodnak, hogy a válaszadók az 
elképzelt ott tartózkodást tartalmasnak, programdúsnak, kellemesnek és élményekkel telinek élték meg, jól érezték magukat. Fontos kiemelni, hogy a narratívákban a ,túl drága”, ,zsúfolt”, ,rosszul karbantartott”, ,"külföldiekre specializálódott” szóöszszetételek is előfordultak, sôt megkérdezettjeink személyzettel kapcsolatos, kiszolgálásbéli problémákat is említenek, melyek a kellemesnek ígérkező élményt könnyen negatívba fordíthatják.

\section{5. Összegzés}

A pandémiát megelőzően túlturizmussal érintett desztinációkban a turizmus tömegessé válása mindennapos problémákat okozott a fogadóközösség számára. E problémák kezelésének egyik lehetséges módja a hosszútávon is vonzó, minden érintett számára elfogadható és hiteles imázs és desztinációmárka kialakítása, amelynek a genius locira építő fogyasztói élmény fontos alapköve lehet.

A Z, Y, X és Baby Boomer generációk tagjai által készített narratívák tanúsága szerint a jelenleg gyakran bulinegyedként hivatkozott VII. kerületben, a széleskörú adottságoknak köszönhetően, minden vizsgált generáció megtalálhatja a számára vonzó élményeket. A VII. kerületben eltöltött idő a magyar fogyasztók számára a kikapcsolódásról, a pihenésről, a szórakozásról, a barátokkal és a családdal közösen megélt, jó hangulatú élményekről szólhat. Ezek mellett az élményígéret szempontjából a szabadság, a stresszmentes pillanatok, a finom ételek és a gasztronómiai változatosság mind a négy generáció számára releváns lehet, legyen szó akár szabadidős, akár turisztikai fogyasztásról. Az önfeledt szórakozás, a különleges kávézók, a látványos, felfedezésre váró helyszínek és az örömteli véletlen találkozások a $Z$ és az $Y$ generációk, míg a színes kultúra, a minőségi színházi élmény, a zsidó kulturális örökség és a nosztalgia az X és a Baby Boomer generációk élményígéretébe emelhető be eredményesen.

A narratívák alapján a VII. kerület olyan történelmi, kulturális, múvészeti és társadalmi értékekkel rendelkezik, amelyek a fogyasztók minden generációja számára vonzó genius locit teremthetnek. A budapesti, de nem a kerületben élő szabadidős fogyasztók és a belföldi turisták szemszögéből vizsgált helyszellem elsősorban az épített örökségben, a hangulatos terekben és utcákban, a különleges hangulatban, a lelassulásban vagy éppen a pezsgésben, a barátokkal, ismerősökkel töltött időben, a véletlen találkozásokban, a színes gasztronómiai élménykínálatban ragadható meg. A VII. kerület genius locijának elemeit a 2. ábrán foglaljuk össze.
2. ábra

\section{Genius loci tényezők csoportosítása a VII.} kerület vonatkozásában

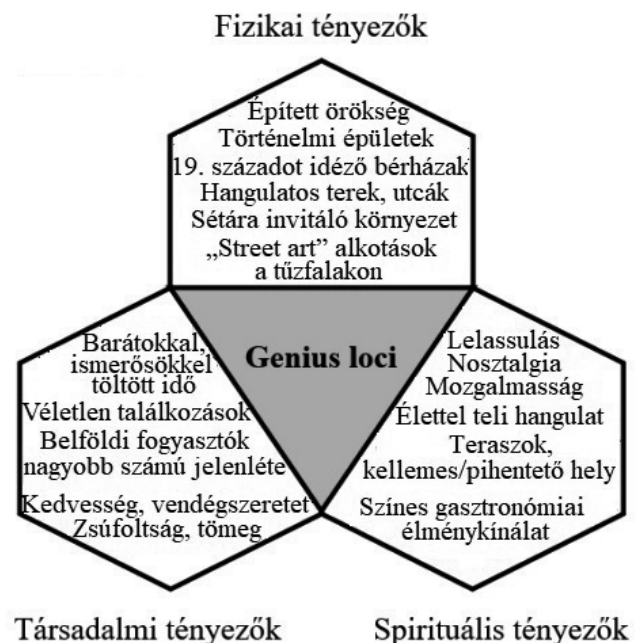

Forrás: saját szerkesztés CHRISTOU et al. (2019) alapján

Kutatási eredményeink érvényessége - a mintaelemszámból és a kutatási módszer sajátosságaiból adódóan - korlátozott. A narratívák esetében nem adott a kutató számára a részletekre való irányított rákérdezés lehetôsége, ily módon teljes mértékben az alanyok által szabadon megírt szövegekre kellett hagyatkoznunk, amelyek nem feltétlenül tartalmaztak minden szükséges információt. Az önkényes mintavételból adódóan megvan a veszélye annak, hogy a válaszadók hasonló gondolkodásmóddal, életstílussal vagy tevékenységi körrel rendelkeznek, ami ugyancsak kutatásunk korlátjaként értelmezhetô.

Jövőbeli kutatási irányként a mintaelemszám növelése és a megkérdezettek körének, elsősorban a helyi lakossággal, illetve a civil szervezetekkel, a vállalkozásokkal, az önkormányzattal való, bóvítése mellett szükséges más kutatási módszerek, például mélyinterjúk, fókuszcsoportos vizsgálatok, netnográfia, fotónapló, kvantitatív megkérdezések alkalmazása is. A minden érintett számára elfogadható élménytényezők és a genius loci, valamint az érintettek mindegyike által kívánatosnak tartott turisztikai imázs és desztinációmárka meghatározásához elengedhetetlen a nevesített kutatási módszerek együttes használata.

A genius loci egy helynek azt a megfoghatatlan és soktényezős karakterisztikáját jelenti, ami fizikai és spirituális módon tapasztalható meg (VECCO 2020). A hely szellemét szándékosan létrehozni nem lehet, ugyanakkor a genius loci is képes a menedzselt változásra, amennyiben ismerjük az érintettek preferenciáit, és élünk a 
befolyásolására alkalmas menedzsmenteszközökkel. A CHRISTOU és szerzőtársai (2019) által megfogalmazottak alapján Belső-Erzsébetváros genius locijának revitalizációját hatékonyan támogathatja:

- a fizikai tényezők esetében: a múemlékvédelem, a parkosítás, a zajkibocsátás csökkentése és a terület tisztaságának és rendezettségének növelése;

- a társadalmi tényezők esetében: a kerület történelmi, kulturális, múvészeti és társadalmi értékeinek szempontjából kiemelkedő jelentőségú részek azonosítása, új célcsoportok megszólítása, az elfogadhatótól eltérő látogatói magatartás szankcionálása;

- a spirituális tényezők tekintetében: a hely jellegének megóvása, a megtapasztalható élmény megfoghatóbbá tétele az érzékszervi észlelést lehetôvé tevő reprezentációs rendszerek magas szinten megvalósuló stimulálása révén.

Ha azonban mindezeknek nem szentelünk kellő figyelmet, akkor a VII. kerület könnyen elveszítheti az autentikus miliővel átitatott vonzerejét. A kerület újrapozícionálása és vendégkörének változ(tat) ása hozzájárulhat a fenntartható és a helyiek érdekeit hosszútávon szolgáló, a helyiek életminőségének javítását célzó várostervezéshez és -fejlesztéshez. Az ilyen módon újrapozícionált kerület nem csak rezisztensebbé válik, hanem később, a nemzetközi turizmus újraéledésével jó eséllyel olyan új, elkötelezett (MITEV-KELEMEN-ERDŐS 2017) szegmenseket tud megszólítani, akiket a VII. kerület lakói is szívesen látnak.

\section{Köszönetnyilvánítás}

Az Innovációs és Technológiai Minisztérium ÚNKP-20-3-II-CORVINUS-81 kódszámú Új Nemzeti Kiválóság Programjának a Nemzeti Kutatási, Fejlesztési és Innovációs Alapból finanszírozott szakmai támogatásával készült.

\section{Felhasznált irodalom}

AHO, S. (2001): Towards a general theory of touristic experiences: Modelling experience process in tourism. Tourism Review. 56(3-4). pp. 33-37. https://doi.org/10.1108/eb058368

APOLLO, M. - RETTINGER, R. (2019): Mountaineering in Cuba: Improvement of true accessibility as an opportunity for regional development of communities outside the tourism enclaves. Current Issues of Tourism. 22(15). 1797-1804.

https://doi.org/10.1080/13683500.2018.1446920
BINKHORST, E. - DEKKER, T. (2009): Agenda for Co-Creation Tourism Experience Research. Journal of Hospitality Marketing $\mathcal{E}$ Management. 18(2-3). pp. 311-327.

https://doi.org/10.1080/19368620802594193

BUTLER, R. W. (1980): The concept of tourism area cycle of evolution: implications for management of resources. Canadian Geographer. 24(1). pp. 5-12. https://doi.org/10.1111/j.1541-0064.1980.tb00970.x

CARU, A. - COVA, B. (2007): Consumption Experience. Routledge, London.

CHRISTOU, P. A. - FARMAKI, A. - SAVERIADES, A. - SPANOU-TRIPINIOTI, E. (2019): The "genius loci" of places that experience intense tourism development. Tourism Management Perspectives. 30. 2019. pp. 19-32. https://doi.org/10.1016/j.tmp.2019.01.002

DOXEY, G. V. (1975): A causation theory of visitor/resident irritants: Methodology and research inferences. Proceedings of the Travel Research Association 6th Annual Conference. pp. 195-198.

GARCIA, D. M. M. (2018): Dark Tourism: Understanding the factors that create memorable tourism experience in the case of Millenials. Budapesti Corvinus Egyetem, Budapest.

HORVÁTH D. - MITEV A. (2015): Alternatív kvalitatív kutatási kézikönyv. Alinea, Budapest.

KELEMEN-ERDŐS A. - MITEV A. (2020): Eszképizmustól az ajánlásig - Élményfokozatok és hatásai a romkocsmákban. Turizmus Bulletin. 20(2). pp. 14-21.

https://doi.org/10.14267/TURBULL.2020v20n2.2

KIM, J. - RITCHIE, J. - McCORMICK, B. (2012): Development of a Scale to Measure Memorable Tourism Experiences. Journal of Travel Research. 51(1). pp. 12-25. https://doi.org/10.1177/0047287510385467

KOENS, K. - POSTMA, A. - PAPP, B. (2018): Is Overtourism Overused? Understanding the Impact of Tourism in a City Context. Sustainability. 10(1)2. 4384. https://doi.org/10.3390/su10124384

KRUCZEK, Z. (2019): Ways to Counteract the Negative Effects of Overtourism at Tourist Attractions and Destinations. Annales Universitatis Mariae Curie-Skłodowska Seria B. 74. 2019. pp. 45-57.

DOI: 10.17951/b.2019.74.45-57.

KULCSÁR N. (2015): A fogyasztói érték és az élmény kontextusa a turisztikai szakirodalomban. Vezetéstudomány. 46(3). pp. 18-25. https://doi.org/10.14267/veztud.2015.03.02

LENGYEL A. (2019): A mindfulness és liminalitás felértékelődése: spirituális elvonulási központok, a fenntartható jövő desztinációi? Turizmus Bulletin. 19(1). pp. 14-24. 
MICHALKÓ G. - IRIMIÁS A. (2011): Csalódásmenedzsment a turizmusban: új szemlélet a turisztikai célterületek irányításában. Marketing \& Menedzsment. 45(2). pp. 4-10.

MICHALKÓ G. - RÁTZ T. (2005): A kulturális turizmus élmény-gazdaságtani szempontjai. In: Enyedi Gy. - Keresztély K. (szerk.): A magyar városok kulturális gazdasága. Magyarország az ezredfordulón. Stratégiai tanulmányok a Magyar Tudományos Akadémián. MTA Társadalomkutató Központ, Budapest. pp. 123-141.

MITEV A. - KELEMEN-ERDŐS A. (2017): Romkocsma mint bricolage: Élményközpontú szolgáltatásérték-teremtés a romkocsmákban. Turizmus Bulletin. 17(1-2). pp. 26-34.

SMITH, M. K. - PINKE-SZIVA, I. - OLT, G. (2019): Overtourism and Resident Resistance in Budapest. Tourism Planning \& Development. 16(4). pp. 376-392. https://doi.org/10.1080/21568316.2019.1595705

PINE, B. J. - GILMORE, J. H. (1998): Welcome to the Experience Economy. Harvard Business Review. 76(4). pp. 96-105.

PINKE-SZIVA,I. -SMITH, M. -OLT, G. -BEREZVAI, Z. (2019): Overtourism and the night-time economy: a case study of Budapest. International Journal of Tourism Cities. 5(1). pp. 1-16. https://doi.org/10.1108/ijtc-04-2018-0028

PINKE-SZIVA I. - KENESEI ZS. - KISS K. - KOLOS K. - KOVÁCS E. - MICHALKÓ G. (2020): Társadalmi innováció a városi desztinációk versenyképességének szolgálatában. Fókuszban az éjszakai gazdaság hatásainak menedzselése. Vezetéstudomány. 51(7-8). pp. 2-12.

https://doi.org/10.14267/VEZTUD.2020.07-08.01
PIZAM, A. - MILMAN, A. (1986): The Social Impacts of Tourism. Tourism Recreation Research. 11(1). pp. 29-33.

SZABÓ K. -HÂMORI B. (2006): Információgazdaság. Digitális kapitalizmus vagy új gazdasági rendszer? Akadémiai Kiadó, Budapest.

UNWTO (2018): Overtourism? Understanding and managing urban tourism growth beyond perceptions. Madrid. pp. 1-12. https://doi.org/10.18111/9789284419999

VECCO, M. (2020): Genius loci as a meta-concept. Journal of Cultural Heritage. 41(1). pp. 225-231. https://doi.org/10.1016/j.culher.2019.07.001

ZÁTORI A. (2014): A turisztikai élményteremtés vizsgálata szolgáltatói szemszögből. Doktori $(\mathrm{PhD})$ értekezés. Budapesti Corvinus Egyetem, Budapest. https://doi.org/10.14267/phd.2014055

ZÁTORI, A. - SMITH, M. K. - PUCZKÓ, L. (2018): Experience-involvement, memorability and authenticity: The service provider's effect on tourist experience. Tourism Management. 67. (August, 2018) pp. 111-126.

https://doi.org/10.1016/j.tourman.2017.12.013

ZEMLA, M. (2020): Reasons and Consequences of Overtourism in Contemporary Cities - Knowledge Gaps and Future Research. Sustainability. 12(5). 1729. https://doi.org/10.3390/su12051729

\section{Internetes források}

PINKE-SZIVA I. (2021): A bulinegyed után is van élet: így alakulhat át Budapest a túlturizmus és a nullturizmus sokkja után. https://forbes.hu/ uzlet/budapest-korona-turizmus-bulinegyed/, Letöltve: 2021. március 26. 